\title{
PENGARUH KEPUASAN KERJA DAN STRES KERJA TERHADAP KINERJA GURU DALAM MENINGKATKAN MUTU AKADEMIK LULUSAN PADA SMA RSBI DI KABUPATEN SIDOARJO
}

\author{
M. Riadhos Solichin*
}

ABSTRACT

This research investigates the effect of job satisfaction and job stress on the teachers 'performance in enhancing graduates' academic achievement in internationally standardized senior highs schools in Sidoarjo. 60 teachers of grade XII teaching the nationally tested subjects were purposefully taken as the sample of the study. Data were gathered by using questionnaire and analysed by employing Partial Least Square Analysis (PLS) in the SmartPLS software. The finding indicates that there is a positive relationship between job satisfaction and teachers' performance. It is predicted that job satisfaction play important role in enhancing the graduates' academic achievement. Secondly, there is contrast relationship between the job stress and teachers' performance. In other words, teachers still work hard in enhancing their students' academic achievement regardless their job stress. Keywords: Job Satisfaction, Job Stress, Teacher's Performance, and Graduates' Academic achievemnt.

\section{PENDAHULUAN}

A danya peningkatan dalam mutu pendidikan tidak terlepas dari peran guru sebagai unsur utama dalam keseluruhan proses pendidikan. Guru mempunyai tugas untuk membimbing, mengarahkan dan juga menjadi teladan yang baik bagi para peserta didiknya, maka dari itu dengan setumpuk tugas serta tanggung jawab yang di embannya guru harus mampu menunjukkan bahwa dia mampu menghasilkan kinerja yang baik demi terciptanya pendidikan yang bermutu. Kepuasan terhadap pekerjaan mampu memberikan stimulus tersendiri bagi seorang individu atau pekerja, seperti guru. Kepuasan kerja yang tinggi atau baik akan membuat seseorang semakin loyal kepada organisasi yang dalam hal ini adalah sekolah. Semakin termotivasi dalam bekerja, bekerja dengan rasa tenang, dan yang lebih penting lagi kepuasan bekerja yang tinggi akan memperbesar kemungkinan tercapainya produktivitas dan motivasi yang tinggi pula.

Robbins (2003) mendefinisikan kepuasan kerja ( Job satisfaction ) mengacu pada sikap individu secara umum terhadap pekerjaannya. Seseorang dengan tingkat kepuasan kerja yang tinggi mempunyai sikap positif terhadap pekerjaannya, sedangkan seseorang yang tidak puas dengan pekerjaannya tersebut mempunyai sikap negatif terhadap pekerjaannya tersebut. Kepuasan kerja guru merupakan sasaran penting dalam manajemen sumber daya manusia, karena secara langsung maupun tidak langsung akan mempengaruhi produktivitas kerja. Suatu gejala yang dapat membuat rusaknya kondisi organisasi sekolah adalah rendahnya kepuasan kerja guru. Rendahnya kepuasan ini bisa memunculkan gejala seperti mangkir dari tugas, malas bekerja, banyaknya keluhan guru, rendahnya

*) Staf Personalia dan Humas PT. Cahaya Mas Makmur Mojokerto 
prestasi kerja, rendahnya kualitas pengajaran, indisipliner guru dan gejala negatif lainnya. Sementara itu, kepuasan kerja yang tinggi menandakan bahwa sebuah organisasi sekolah telah dikelola dengan baik dengan manajemen yang efektif. "Kepuasan kerja yang tinggi menunjukkan kesesuaian antara harapan guru dengan imbalan yang disediakan oleh organisasi" (Fatah, 2001).

Wexley dan Yukl (2005) mengemukakan lima dimensi inti dari suatu pekerjaan yang menyebabkan kepuasan kerja, yaitu : (1) variasi keterampilan (Skill variety) yaitu tugas yang dirasakan sebagai bagian dari pekerjaan yang lebih besar dan satu kelengkapan, dimana pekerjaan yang dirasakan tidak satu kelengkapan tersendiri akan menimbulkan rasa tidak puas. (2) Identitas pekerjaan (task identity) yaitu mengerjakan suatu pekerjaan mulai dari permulaan hingga berakhir dengan hasil yang nyata, seseorang akan lebih termotivasi untuk menyelesaikan pekerjaannya dengan baik apabila karyawan tersebut dapat memahami lebih jauh bagaimana produk akhir dari pekerjaan tersebut. (3) Kepentingan pekerjaan (task significancy) yaitu apabila tugas dirasakan penting dan berarti oleh karyawan, maka karyawan tersebut cenderung puas terhadap pekerjaannya. (4) Otonomi (autonomy) yaitu tentang kesempatan untuk mengatur pekerjaan sendiri, kebebasan melaksanakan pekerjaan, kebebasan berfikir dan bertindak dalam pelaksanaan pekerjaan akan lebih puas terhadap hasil pekerjaanya. (5) Umpan balik pekerjaan itu sendiri (feedback from job it self) dalam hal ini meliputi cara melaksanakan pekerjaan dan hasil pekerjaan, seseorang yang merasa dirinya mendapat umpan balik dalam pekerjaannya akan lebih puas terhadap pekerjaannya. Berdasarkan penelitian yang dilakukan oleh Bhuain dan Menguc (2002) menyatakan bahwa karakteristik pekerjaan yang terdiri dari otonomi (autonomy), variasi keterampilan (skill variety), identitas tugas (taks identity) dan umpan balik (feedback) berpengaruh positif terhadap kepuasan kerja karyawan.

Namun, dewasa ini tuntutan dalam bekerja yang semakin tinggi menimbulkan banyaknya tekanan yang harus dihadapi oleh guru. Tekanan yang terus menerus dapat memicu gangguan yang disebut stres. Penelitian yang dilakukan oleh Sheena Johnson et al. (2005) dalam jurnalnya meneliti 26 macam profesi pekerjaan di Inggris dan salah satunya adalah profesi guru. Dalam penelitiannya disebutkan bahwa beban kerja dan tekanan waktu, dengan kata lain faktor intrinsic to job merupakan faktor stres yang berpengaruh dominan terhadap kinerja guru. Di sisi lain, persaingan sehat antar sekolah yang ingin menjadikan sekolahnya mempunyai predikat sekolah unggulan, membuat setiap sekolah berupaya untuk meningkatkan nilai dan citra sekolahnya. Oleh karenanya, wajar apabila para guru yang bersangkutan diharapkan dapat memberikan kontribusi semaksimal mungkin, dimana kontribusi tersebut tercermin pada sejauh mana kinerja yang dicapai oleh para guru. Apabila stres kerja yang ada berlebihan, dengan kata lain guru tidak mampu mengatasinya, maka stres kerja tersebut dapat merusak kinerja, dan tentunya kondisi tersebut akan sangat merugikan sekolah tempat guru tersebut bekerja. Rivai (2008) menjelaskan bahwa stres kerja ialah "suatu kondisi ketegangan yang menciptakan adanya ketidakseimbangan fisik dan psikis, yang mempengaruhi emosi, proses berpikir, dan kondisi seorang karyawan". Penyebab stress disebut stressor. Luthans dalam Akhlaq et al. (2010) menyebutkan "sumber stres dari luar organisasi mencakup perubahan sosial dan teknologi, ekonomi dan kondisi keuangan, ras, dan kondisi masyarakat". Kemajuan ilmu pengetahuan di bidang teknologi dapat membuat keterampilan dan pengalaman seseorang menjadi ketinggalan dan tidak berguna, sehingga orang tersebut merasa tidak mampu untuk mengikuti perkembangan teknologi yang ada, seperti komputer, otomatisasi, dan 
lain-lain. Kebijakan perekonomian yang ditetapkan oleh pemerintah dapat menyebabkan individu mengalami stres, hal tersebut dapat dibuktikan dengan adanya aksi penuntutan kenaikan gaji pegawai.

Stres kerja juga dapat bersumber dari dalam organisasi. Menurut Cooper dan Marshall dalam Akhlaq et al. (2010), sumber utama stres di tempat kerja diantaranya : (1) Faktor intrinsic to job mencakup beban kerja yang berlebihan dan tekanan waktu. Beban kerja yang tidak sebanding dengan kemampuan fisik maupun keahlian karyawan dan keterbatasan waktu yang tersedia untuk menyelesaikannya, dapat membuat seseorang merasa lebih tertekan. (2) Faktor role in organization, yaitu mencakup ambiguitas peran, konflik peran, dan tanggung jawab peran. Kurangnya informasi untuk dapat melaksanakan suatu peran dapat menyebabkan seseorang mengalami ambiguitas peran atau ketidakjelasan peran, sehingga pekerja tersebut tidak mengerti apa yang harus dilakukannya. Sedangkan konflik peran dapat disebabkan oleh peran yang tidak diharapkan atau bertentangan dengan nilainilai dan keyakinan pribadi pekerja. Konflik peran juga bias timbul akibat adanya tugas yang tidak sesuai dengan peran seseorang di organisasi. Selain itu, dalam menjalankan suatu peran, seseorang pasti tidak lepas dari tanggung jawab. Tuntutan untuk memenuhi tanggung jawab sesuai dengan peran yang dijalankan, merupakan tekanan tersendiri bagi seorang pekerja. (3) Faktor relationship at work mencakup ketidakmampuan menjalin hubungan dengan atasan, bawahan, atau rekan kerja dan kesulitan dalam menjalin delegasi. Apabila seseorang tidak mampu menjalin hubungan yang harmonis, baik dengan atasan, bawahan atau rekan kerja, tentunya hal tersebut dapat menimbulkan perasaan tertekan bagi pekerja tersebut, karena bagaimanapun juga, manusia adalah makhluk sosial yang dalam hidupnya membutuhkan interaksi dengan sesama, tidak terkecuali di tempat kerja. Pada masalah kesulitan dalam delegasi biasanya dikarenakan adanya rasa kurang percaya terhadap orang lain atau tidak mau menerima tambahan tanggung jawab.

Beberapa tahun ini pemerintah telah melakukan upaya besar-besaran untuk meningkatkan kualitas pendidikan. Pemerintah khususnya melalui Departemen Pendidikan dan Kebudayaan terus melakukan perbaikan dan pembaharuan dalam sistem pendidikan. Upaya tersebut diantaranya dengan menetapkan standar kelulusan bagi siswa sekolah dasar, menengah pertama dan menengah atas yang tiap tahun semakin meningkat. Selain itu lahirnya Undang-Undang No. 14 tahun 2005 tentang Standar Nasional Pendidikan merupakan kebijakan pemerintah yang di dalamnya memuat usaha pemerintah untuk menata dan memperbaiki mutu guru di Indonesia. Upaya pemerintah salah satunya adalah membentuk sekolah yang mempunyai standar internasional yaitu Rintisan Sekolah Bertaraf Internasional (RSBI) dimana Sekolah yang menyiapkan peserta didik berdasarkan Standar Nasional Pendidikan (SNP) Indonesia dan bertaraf Internasional sehingga diharapkan lulusannya memiliki kemampuan daya saing internasional.

Salah satu indikator dari apakah suatu RSBI memiliki kualitas yang setingkat lebih tinggi dari sekolah reguler adalah dengan mengetahui kualitas siswa dan gurunya. Idealnya, baik siswa maupun guru RSBI memiliki kemampuan akademik di atas rata-rata siswa dan guru sekolah-sekolah reguler. Dalam kaitan dengan kinerja RSBI hal semacam ini penting diketahui untuk memastikan bahwa tujuan penyelenggaraan RSBI yaitu untuk menghasilkan peserta didik yang lebih bermutu bisa tercapai. Pusat Penelitian Kebijakan, Balitbang Kemdiknas pada tahun 2010 melakukan penelitian untuk mengetahui kualitas RSBI di Indonesia. Berdasarkan hasil penelitian dan evaluasi terhadap sekolah rintisan sekolah bertaraf internasional, tidak ditemukan perbedaan signifikan mutu sekolah RSBI 
dengan sekolah reguler. Program Rintisan Sekolah Bertaraf Internasional tidak membawa pengaruh banyak pada peningkatan mutu akademis. Bahkan tidak ada korelasi signifikan peningkatan mutu akademis di sekolah yang menyandang status RSBI dibanding saat masih berstatus sekolah reguler. Peningkatan kualitas hanya nyata terlihat pada pembangunan fisik semata (Polkamnas, 20 Maret 2012).

Penelitian ini dilakukan pada SMA RSBI di Kabupaten Sidoarjo, antara lain : SMA Negeri 1 Sidoarjo, SMA Muhammadiyah 2 Sidoarjo, dan SMA Negeri 1 Krian. Sekolahsekolah tersebut merupakan sekolah favorit dan menjadi tujuan para siswa di wilayah Sidoarjo karena merupakan sekolah unggulan dimana memiliki prestasi akademik maupun non akademik yang baik. Para siswa lulusan SMA tersebut selain memiliki prestasi yang baik juga banyak diterima di berbagai Perguruan Tinggi Negeri (PTN) di Indonesia. Hal tersebut menandakan bahwa kualitas mutu akademik yang dimiliki oleh sekolahsekolah tersebut cukup baik dimana mutu akademik lulusan merupakan kualitas keberhasilan siswa di bidang akademik dalam proses kegiatan belajar-mengajar yang diikutinya di sekolah yang ditunjukkan oleh nilai Ujian Nasional. Dari hasil Ujian Nasional akan menggambarkan tingkat pencapaian siswa mulai dari tingkat sekolah hingga nasional dan hasil UN dimanfaatkan untuk peningkatan mutu pendidikan (Hariwibowo, 1994). Berdasarkan hal tersebut, peneliti ingin mengetahui apakah kinerja pembelajaran guru tersebut disebabkan dan dipengaruhi oleh kepuasan atas pekerjaan dan stres kerja yang dialami oleh para guru. Oleh karena itu, penelitian ini ditujukan untuk menganalisis bagaimana pengaruh kepuasan dan stres atas pekerjaaan terhadap kinerja guru dalam meningkatkan mutu akademik lulusan pada SMA RSBI di Kabupaten Sidoarjo.

Penelitian sebelumnya mengenai pengaruh kepuasan kerja terhadap kinerja yang pernah dilakukan adalah penelitian oleh Bhuain dan Menguc (2002) menyatakan bahwa faktor pekerjaan yang terdiri dari otonomi (autonomy), variasi keterampilan (skill variety), identitas tugas (taks identity) dan umpan balik (feedback) berpengaruh positif terhadap kepuasan kerja karyawan yang akhirnya secara langsung dapat meningkatkan kinerja dan prestasi karyawan. Dalam penelitian Manzoor et.al (2011) memberikan hasil bahwa kepuasan kerja lebih tinggi dibanding dengan stres kerja yang dialami oleh pegawai di universitas baik itu staf pengajar maupun staf teknis. Sedangkan Salami et.al (2010) dalam penelitiannya juga menemukan bahwa stres kerja berpengaruh negatif terhadap kinerja manajer.

Berdasarkan penelitian yang dilakukan oleh Akhlaq et.al (2010) berhasil mengidentifikasi faktor-faktor stres dan pengaruhnya terhadap kinerja guru. Dari penelitian tersebut ditemukan bahwa guru-guru mengalami terlalu banyak pekerjaan dalam waktu satu hari sehingga tidak memiliki waktu untuk melakukan hal lain, kurangnya waktu untuk bersantai, dan merasa tidak nyaman membuang-buang waktu. Lebih lanjut, ditemukan bahwa hal-hal yang dialami oleh para guru tersebut secara langsung mempengaruhi kinerja yang ditunjukkan dalam bentuk pengetahuan yang kurang tentang materi pelajaran, ketidakmampuan untuk memperkenalkan variasi dalam metode pengajaran, ketidakterlibatan masalah sekolah selain akademisi, ketidakhadiran, ketidakmampuan untuk menjaga hubungan yang baik dengan rekan kerja, dan lain-lain. Oleh sebab itu, stres kerja sebagai salah satu variabel yang mempengaruhi kinerja, perlu untuk dikaji selain daripada kepuasan kerja.

Penelitian mengenai kinerja guru pernah dilakukan oleh Subroto (2010) dalam penelitian tersebut menemukan bahwa kinerja guru memiliki pengaruh terhadap mutu pendi- 
dikan di sekolah, dengan pemilikan kemampuan yang memadai, pemahaman akan apa yang menjadi wewenang dan tanggung jawabnya serta dibarengi adanya dorongan yang kuat dari dalam diri guru untuk melakukan kegiatan belajar mengajarnya, mereka akan tekun dalam bekerja, bekerja keras, penuh inisiatif dan kreativitas. Dengan kondisi seperti ini akan cenderung meningkatkan kepuasan para siswanya, yang pada gilirannya menuju kearah peningkatan mutu pendidikan. Penelitian lainnya dilakukan oleh Yuniastini dkk. (2005) meneliti tentang Analisis Pengaruh Kinerja Dosen dan Proses Belajar Mengajar Terhadap Prestasi Mahasiswa. Hasil dari penelitian tersebut menemukan bahwa semakin tinggi kinerja dosen dalam perencanaan pengajaran, pelaksanaan pengajaran, dan evaluasi pengajaran berpengaruh dengan meningkatnya prestasi belajar mahasiswa.

Berdasarkan tinjauan teoritis dan hasil penelitian terdahulu, serta tujuan penelitian yang hendak dicapai, maka hipotesis dalam penelitian ini adalah :

1. Diduga kepuasan kerja berpengaruh signifikan terhadap kinerja guru SMA RSBI di Kabupaten Sidoarjo.

2. Diduga stres kerja berpengaruh signifikan terhadap kinerja guru SMA RSBI di Kabupaten Sidoarjo.

\section{METODE PENELITIAN}

Rancangan penelitian dilakukan dengan pendekatan kuantitatif dengan tujuan untuk menguji hipotesa serta mengetahui signifikansi dari pengaruh variabel : kepuasan kerja dan stres kerja terhadap kinerja guru RSBI di Kabupaten Sidoarjo dalam meningkatkan mutu akademik lulusan. Teknik yang digunakan dalam pengambilan sampel dalam penelitian ini adalah dengan metode purposive sample. Dalam penelitian ini kriteria responden yang dibatasi hanya pada pada guru yang mengajar pada kelas XII khusus mata pelajaran yang di ujikan pada ujian nasional antara lain guru bidang studi Matematika, Bahasa Indonesia, Bahasa Inggris, IPA, dan IPS di SMA RSBI yang ada di Kabupaten Sidoarjo, yakni : SMA Negeri 1 Sidoarjo, SMA Muhammadiyah 2 Sidoarjo, dan SMA Negeri 1 Krian.

Data yang digunakan dalam penelitian ini terbagi menjadi dua yaitu data primer dan data sekunder. Adapun data primer, yaitu data yang diperoleh langsung dari responden yakni guru melalui angket/kuesioner kepuasan kerja, stres kerja, dan kinerja guru yang diisi oleh guru. Sedangkan data sekunder, yaitu data yang diperoleh berasal dari studi kepustakaan atau sumber lain, disini menggunakan data nilai Ujian Nasional dan informasi dari masing-masing sekolah dan juga Dinas Pendidikan Kabupaten Sidoarjo. Teknik analisis data yang digunakan dalam penelitian ini menggunakan analisis statistik deskriptif dan Partial Least Square (PLS).

\section{HASIL PENELITIAN DAN PEMBAHASAN}

\section{Hasil Penelitian}

Pada penelitian ini untuk menguji hipotesis yang digunakan metode Partial Least Square (PLS). PLS tidak mengasumsikan adanya distribusi tertentu untuk estimasi parameter, maka teknik parametrik untuk menguji signifikansi parameter tidak diperlukan. Model evaluasi PLS berdasarkan pengukuran prediksi dan mempunyai sifat non parametrik. Oleh karena dalam penelitian ini indikatronya refleksif, maka analisis dengan 
PLS ada 2 tahap pengujian, yaitu (1) analisis outer model atau measurement model melalui convergent dan discriminant validity serta composite reliability dan (2) pengujian inner model atau model struktural.

\section{Pengujian Outer Model \\ Uji Convergent Validity}

Uji Convergent validity digunakan untuk menguji apakah indikator-indikator yang digunakan penelitian ini telah mengukur konstruk atau variabel secara akurat. Dari hasil analisis menunjukkan bahwa semua loading factor memiliki nilai diatas 0,50. Dengan demikian dapat disimpulkan bahwa konstruk mempunyai convergent validity yang baik dan reliabel.

Uji Discriminant Validity

Discriminant validity digunakan untuk menguji apakah indikator-indikator suatu konstruk tidak berkorelasi tinggi dengan indikator dari konstruk lain atau paling tidak indikator-indikator tersebut berkorelasi lebih rendah dengan indikator-indikator konstruk yang lain. Selain memenuhi kriteria validitas konvergen, juga harus memenuhi criteria discriminant validity, yaitu untuk membuktikan bahwa alat ukur tersebut tidak mengukur konstruk lainnya. Discriminant validity pada analisis PLS dilakukan dengan (1) membandingkan loading dengan cross-loading, (2) average variance extracted (AVE), dan (3) membandingkan akar kuadrat AVE dengan korelasi antar variable laten.

Nilai cross loading menunjukkan adanya discriminant validity yang baik karena nilai korelasi indikator terhadap konstruknya lebih tinggi dibandingkan nilai korelasi indikator dengan konstruk lainnya. Sehingga dapat diambil kesimpulan bahwa konstruk laten memprediksi indikator pada blok mereka lebih baik dibandingkan dengan indikator di blok lain.

Di samping uji validitas konstruk, dilakukan juga uji reliabilitas konstruk yang diukur dengan composite reliability dari blok indikator yang mengukur konstruk. Konstruk dinyatakan reliabel jika memiliki nilai composite reliability di atas 0,70. Dari hasil output SmartPLS dalam penelitian ini, semua konstruk memiliki nilai composite reliability di atas 0,70 . Jadi dapat disimpulkan bahwa konstruk memiliki reliabititas yang baik. Selain dari composite reliability, untuk menilai reliabilitas suatu konstruk dapat dilakukan dengan melihat Average Variance Extracted (AVE) dan membandingkan nilai akar AVE dengan nilai korelasi antar konstruk. Dari hasil analisis menunjukkan nilai akar AVE ternyata lebih tinggi dibandingkan dengan nilai korelasi antara konstruk dengan konstruk lainnya dalam penelitian ini. Hal ini berarti bahwa semua konstruk dalam model yang diestimasi dalam penelitian ini memenuhi kriteria discriminant validity.

\section{Pengujian Model Struktural (Inner Model)}

Setelah model yang diestimasi memenuhi kriteria discriminant validity, selanjutnya dilakukan pengujian model struktural (inner model). Menilai inner model adalah melihat hubungan antara konstruk laten dengan melihat hasil estimasi koefisien parameter path dan tingkat signifikansinya (Ghozali, 2008). Hasil analisis menunjukkan bahwa nilai Rsquare kinerja guru adalah sebesar 0,552. Hal ini berarti bahwa kepuasan kerja dan stres kerja yang dialami oleh guru mampu mempengaruhi kinerja sebesar 55\% sedangkan sisanya dijelaskan oleh variabel lain diluar penelitian ini.

Dasar yang digunakan dalam menguji hipotesis adalah nilai yang terdapat pada out- 
put result for inner weight berikut ini:

Tabel 1

Result for Inner Weight

\begin{tabular}{|c|c|c|c|c|c|}
\hline & $\begin{array}{c}\text { Original } \\
\text { Sample } \\
\text { (O) }\end{array}$ & $\begin{array}{c}\text { Sample } \\
\text { Mean } \\
\text { (M) }\end{array}$ & $\begin{array}{c}\text { Standard } \\
\text { Deviation } \\
\text { (STDEV) }\end{array}$ & $\begin{array}{c}\text { Standard } \\
\text { Error } \\
\text { (STERR) }\end{array}$ & $\begin{array}{c}\text { T Statistics } \\
(\text { (|O/STERR) }\end{array}$ \\
\hline KK -> KG & 0,599 & 0,454 & 0,230 & 0,220 & 3,233 \\
\hline SK -> KG & 0,307 & 0,287 & 0,242 & 0,242 & 0,995 \\
\hline
\end{tabular}

Sumber: Output SmartPLS

Berdasarkan hasil uji hipotesis disimpulkan, bahwa kepuasan kerja yang dirasakan oleh para guru berpengaruh signifikan terhadap kinerjanya dengan koefisien parameter sebesar 0,599. Hal tersebut dapat dibuktikan dengan melihat nilai T-statistik yang berada diatas 1,96 yakni sebesar 3,233. Dengan demikian, hipotesis H1 dalam penelitian ini diterima. Stres kerja yang dirasakan oleh para guru berpengaruh tidak signifikan terhadap kinerjanya dengan koefisien parameter sebesar 0,307. Hal tersebut dapat dibuktikan dengan melihat nilai T-statistik yang berada dibawah 1,96 yakni sebesar 0,995. Dengan demikian, hipotesis $\mathrm{H} 2$ dalam penelitian ini ditolak.

\section{Pembahasan}

1. Pengaruh Variabel Kepuasan Kerja Terhadap Kinerja Guru dalam Meningkatkan Mutu Akademik Lulusan

Berdasarkan uji hipotesis bahwa variabel kepuasan kerja memiliki pengaruh signifikan terhadap kinerja guru, hal ini sesuai dengan penelitian yang dilakukan oleh Bhuain and Menguc (2002) dimana sumber kepuasan instrinsik yang berasal dari dalam individu yang berhubungan dengan kinerja antara lain kepuasan intrinsik dilihat dari pekerjaan itu sendiri (work it self) dimana termasuk kesempatan untuk berkontribusi untuk kesejahteraan, keterlibatan dalam pelaksanaan tugas yang beragam dan otonomi berpengaruh positif terhadap kepuasan kerja karyawan. Selain itu dijelaskan juga bahwa terbukanya kesempatan bagi guru untuk terlibat dalam pengambilan keputusan merupakan sumber penting dalam kepuasan secara intrinsik. Dengan kata lain, individu yang memiliki kepuasan atas pekerjaannya sendiri cenderung memiliki kepuasan kerja yang tinggi.

Penelitian ini senada dengan penelitian yang pernah dilakukan oleh Manzoor et. Al (2011) dengan judul A Study of Job Stress and Job Satisfaction Among Universities Faculty in Lahore Pakistan memberikan hasil bahwa kepuasan kerja lebih tinggi dibanding dengan stres kerja yang dialami oleh pegawai di universitas baik itu staf pengajar maupun staf teknis. Para pegawai di universitas tersebut meskipun mengalami stres kerja tetapi mereka juga sangat puas akan pekerjaannya karena manajemen universitas yang cukup baik dimana menciptakan susana kondusif dalam lingkungan kerja sehingga pekerjaan bukan lagi menjadi suatu beban.

Terdapat beberapa alasan terhadap hasil penelitian ini, dimana faktor Skill Variety, Task Identity, Task Significance, Autonomy, dan Feedback from job it self berpengaruh positif dan signifikan terhadap kinerja guru SMA RSBI di kabupaten Sidoarjo. Sekolah RSBI sesuai dengan kurikulum internasional yang dianut diwajibkan untuk menggunakan bahasa inggris serta mampu menggunakan teknologi informasi dalam melakukan kegiatan 
belajar-mengajar. Hal ini dirasakan guru justru sebagai tantangan untuk bisa menguasainya sehingga bukan dijadikan suatu beban melainkan diharapkan keterampilan mereka akan meningkat sehingga mereka merasa lebih puas karena kinerja mereka semakin baik.

Para guru yang mengajar di sekolah RSBI umumnya mereka merasa bangga bisa mengajar di sebuah sekolah terbaik dan berkualitas sehingga mereka merasa mengajar di sekolah tersebut merupakan tugas yang sangat penting dan berarti, karena mengajar disekolah RSBI dimana input siswanya merupakan siswa-siswa yang cukup pandai, disini guru justru merasa tertantang dan memiliki tanggung jawab yang lebih besar dalam mengajar siswa-siswa tersebut sehingga guru merasa puas akan jerih payahnya dalam mengajar karena output siswa yang dihasilkan banyak memiliki prestasi, baik prestasi akademik maupun non akademik. Ditambah mereka mendapat umpan balik dari kepala sekolah dan wali murid sehingga mereka merasa hasil kerja kerasnya dihargai oleh orang lain.

Walaupun tanggung jawab dan pekerjaan yang semakin bertambah bagi guru RSBI hal ini seimbang dengan hasil yang diperoleh karena sebagian besar guru telah tersertifikasi pendidik, berarti secara gaji atau kompensasi sudah dirasakan cukup layak dan puas. Ditambah sarana-prasarana sekolah RSBI yang memang sejak awal telah dituntut untuk lebih baik dan lengkap serta disertai dengan teknologi IT yang cukup baik serta memadai, hal ini menjadikan guru merasa puas karena saran-prasarana yang baik secara tidak langsung akan mendukung para guru dalam meningkatkan kinerja pembelajaran mereka.

Dari analisis data telah didapatkan hasil bahwa kepuasan kerja yang berpengaruh positif dan signifikan terhadap kinerja guru SMA RSBI di kabupaten Sidoarjo dibandingkan dengan stres kerja. Kepuasan kerja yang tinggi dirasakan oleh guru sangat membantu dalam meningkatkan kinerja pembelajarannya. Hal tersebut senada dengan penelitian Yuniastini (2006), penelitiannya yang menganalisis pengaruh kinerja dosen terhadap prestasi belajar mahasiswa. Hasil dari penelitian tersebut membuktikan bahwa kinerja dosen yang meliputi perencanaan, pelaksanaan, dan evaluasi pengajaran yang dilakukan oleh dosen berpengaruh terhadap prestasi belajar mahasiswa. Semakin tinggi kinerja dosen, semakin tinggi prestasi belajar mahasiswa.

Melihat tingkat kinerja guru dalam pembelajaran, didapat hasil dari analisis bahwa responden menilai kinerjanya dalam melakukan kegiatan belajar mengajar rata-rata sangat baik. Proses pembelajaran yang dilaksanakan oleh guru selalu didukung dengan bahan ajar, silabus dan RPP yang sudah dipersiapkan lebih dulu oleh guru, sudah sepenuhnya dengan baik dilaksanakan sebagaimana yang diharapkan dalam persyaratan pembelajaran berbasisis kompetensi. Dari tiga komponen utama yang dapat dilaksanakan, seperti : kompetensi dasar, materi pokok, dan indikator pencapaian hasil belajar juga telah dilengkapi tiga komponen yang aplikatif, yaitu : (a) kompetensi dasar, yang termuat dalam KBK; (b) bahan ajar (modul), buku yang dapat menjabarkan bagaimana kurikulum diaplikasikan dalam aktivitas pembelajaran siswa dalam kelas; dan (c) sistem penilaian, yaitu strategi dan cara penilaian yang menjabarkan tentang bagaimana melakukan penilaian terhadap setiap kompetensi yang ingin dicapai pada setiap materi pelajaran.

Keterampilan guru dalam mengelola pembelajaran ditunjukkan guru dalam menyelesaikan tugas yang berhubungan dengan materi pelajaran yang dapat diwujudkannya dalam tugas mengajar untuk menjadikan siswa belajar dengan berbagai cara dan teknik, melalui perencanaan, pengorganisasian, pelaksanaan, dan evaluasi pembelajaran yang akhirnya berdampak pada mutu akademik lulusan. Mutu akademik lulusan merupakan gradasi pencapaian lulusan dalam tes kemampuan akademik, dalam hal ini Ujian Nasional 
(UN). Dengan demikian mutu akademik lulusan merupakan kualitas keberhasilan siswa di bidang akademik dalam proses kegiatan belajar-mengajar yang diikutinya di sekolah. Dalam penelitian ini dari hasil nilai akhir ujian nasional rata-rata lulusan SMA yang berstatus RSBI mendapatkan nilai yang cukup tinggi dan ungul dari sekolah reguler lainnya. Dalam tabel dibawah ini akan ditunjukkan pencapaian hasil ujian nasional dari ketiga sekolah yang menyandang status RSBI di kabupaten Sidoarjo untuk jurusan IPA dan IPS tahun 2012.

Tabel 2

Hasil Ujian Nasional Jurusan IPA \& IPS Tahun 2012

\begin{tabular}{|c|c|c|c|}
\hline Mata Pelajaran & SMAN I Sidoarjo & SMA Muh 2 Sidoarjo & SMAN l Krian \\
\hline \multicolumn{4}{|c|}{ Program IPA } \\
\hline B. Indonesia & 8,86 & 8,53 & 9,03 \\
\hline B. Inggris & 8,56 & 8,23 & 8,68 \\
\hline Matematika & 8,95 & 8,99 & 9,32 \\
\hline Fisika & 8,75 & 8,30 & 9,00 \\
\hline Kimia & 9,24 & 8,68 & 9,24 \\
\hline Biologi & 8,79 & 8,72 & 9,29 \\
\hline TOTAL & 53,15 & 51,45 & 54,56 \\
\hline \multicolumn{4}{|c|}{ Program IPS } \\
\hline B. Indonesia & 8,87 & 8,38 & 9,03 \\
\hline B. Inggris & 8,42 & 7,98 & 8,21 \\
\hline Matematika & 8,90 & 8,96 & 9,23 \\
\hline Ekonomi & 8,33 & 8,28 & 8,91 \\
\hline Sosiologi & 8,87 & 8,65 & 9,11 \\
\hline Geografi & 8,64 & 8,33 & 9,10 \\
\hline TOTAL & 52,03 & 50,58 & 53,59 \\
\hline
\end{tabular}

Sumber: Diknas Kab. Sidoarjo. 2012

Dari data tersebut diatas rata-rata nilai ujian akhir nasional SMA RSBI di kabupaten Sidoarjo cukup baik. Dari ketiga sekolah tersebut dua diantaranya yakni SMA Negeri 1 Krian dan SMA Negeri 1 Sidoarjo menepati urutan teratas perolehan nilai ujian akhir nasional dari seluruh SMA/MA sederajat sekabupaten Sidoarjo. Sedangkan klasifikasi kemampuan akademik sekolah beradasarkan penilaian dari Diknas (2009) adalah sebagai berikut :
a. Baik Sekali
: A (rata-rata nilai $\mathrm{UN}>7,50)$
b. Baik
: $\mathrm{B}(6,50<$ rata-rata nilai $\mathrm{UN}<7,50)$
c. Sedang
: C $(5,50<$ rata-rata nilai $\mathrm{UN}<6,50)$
d. Kurang
: D $(4,50<$ rata-rata nilai $\mathrm{UN}<5,50)$
e. Kurang sekali
: E (rata-rata nilai $\mathrm{UN}<4,50)$.

Dari data perolehan nilai ujian nasional ketiga sekolah RSBI di atas dapat diketahui bahwa rata-rata setiap mata pelajaran yang dujikan mendapatkan nilai $>7,50$; ini berarti ketiga sekolah RSBI di kabupaten Sidoarjo dalam klasifikasi sekolah dengan kemampuan akademik baik sekali atau sekolah dengan klasifikasi (A) dan untuk tingkat kelulusan, semua sekolah SMA RSBI tersebut mencapai 100\% atau artinya semua siswa lulus dalam ujian nasional. 
2. Pengaruh Variabel Stres Kerja Terhadap Kinerja Guru dalam Meningkatkan Mutu Akademik Lulusan

Berdasarkan uji hipotesis bahwa variabel stres kerja memiliki pengaruh tidak signifikan terhadap kinerja guru dalam meningkatkan mutu akademik lulusan, hal ini tidak sesuai dengan penelitian yang dilakukan oleh Akhlaq et al. (2010) Dari penelitian tersebut ditemukan bahwa guru-guru di Rawalpandi memiliki tingkat stres yang cukup tinggi dimana mereka mengalami terlalu banyak pekerjaan dalam waktu satu hari sehingga tidak memiliki waktu untuk melakukan hal lain, kurangnya waktu untuk bersantai, dan merasa tidak nyaman membuang-buang waktu. Lebih lanjut, ditemukan bahwa hal-hal yang dialami oleh para guru tersebut secara langsung mempengaruhi kinerja yang ditunjukkan dalam bentuk pengetahuan yang kurang tentang materi pelajaran, ketidakmampuan untuk memperkenalkan variasi dalam metode pengajaran, ketidakterlibatan masalah sekolah selain akademisi, ketidakmampuan untuk menjaga hubungan yang baik dengan rekan kerja, dan lain-lain. Hal ini justru berkebalikan dengan hasil penelitian ini dimana dalam penelitian ini, dimana faktor intrinsic to job merupakan faktor job stressor yang berkaitan dengan segala sesuatu yang terkandung dalam suatu profesi pekerjaan. Pada SMA RSBI di Sidoarjo ternyata para guru tidak merasa terbebani dengan tugas-tugas yang ada, walaupun para guru tersebut hanya memiliki waktu yang sedikit untuk bersantai di tempat kerja, merasa waktu berjalan sangat cepat, dan terdapat lebih dari satu macam tugas yang harus diselesaikan pada waktu yang sama. Para guru mampu menangani beban kerjanya dengan baik dan mempunyai manajemen waktu yang bagus.

Faktor role in organization merupakan faktor job stressor yang berkaitan dengan peran yang dijabat oleh seseorang dalam menjalankan tugasnya. Dalam penelitian ini, faktor role in organization menunjukkan pengaruh tidak signifikan terhadap kinerja guru SMA RSBI di kabupaten Sidoarjo. Diperoleh hasil bahwa para guru mendapatkan informasi yang jelas mengenai tujuan dan peran yang dijalankannya, sangat paham dengan tugas yang akan dikerjakannya, tidak mengejakan tugas yang bukan baginya, tidak menjalankan tugas yang menurutnya tidak perlu, tidak menjadi lelah apabila memonitor perilaku murid, dan tidak menjadi tertekan apabila harus mengajar siswa yang kurang pandai. Hal ini menunjukkan bahwa para guru mempunyai keterampilan dan wawasan yang luas dalam menjalankan perannya.

Faktor relationship at work merupakan faktor job stressor yang berkaitan dengan hubungan sosial seseorang di tempat kerja. Dalam penelitian ini, faktor relationship at work menunjukkan pengaruh yang tidak signifikan terhadap kinerja guru SMA RSBI di kabupaten Sidoarjo. Hal ini karena fenomena di lapangan menunjukkan bahwa stres yang berasal dari faktor relationship at work adalah rendah. Dengan demikian dapat diartikan bahwa ketidakmampuan untuk menjalin relasi diantara guru adalah rendah. Para guru tidak menemukan kendala dalam menjalin komunikasi dengan rekan kerja, tidak merasa tersinggung apabila ada rekan kerja yang menegur kesalahannya, tetap tenang apabila mendelegasikan tanggung jawab kepada rekan kerja, dan tetap menerima limpahan wewenang dari atasan walaupun dapat menambah tanggung jawab yang ada. Hal ini menunjukkan bahwa para guru saling menghormati dan menghargai satu sama lainnya, memiliki kemamapuan untuk memahami diri sendiri juga sesama, dan terdapat rasa saling percaya dan keakraban yang terjalin dengan baik.

Terdapat beberapa alasan terhadap hasil penelitian ini, dimana faktor intrinsic to job, faktor role in organization, dan faktor relationship at work berpengaruh tidak signifikan 
terhadap kinerja guru SMA RSBI di kabupaten Sidoarjo. Alasan pertama adalah adanya kegiatan untuk berdoa bersama pada setiap pagi hari sebelum memulai pelajaran. Dengan, kegiatan tersebut, tentunya kan membawa rasa tenang dan nyaman untuk memulai kegiatan belajar mengajar ditambah dengan sholat dhuha berjamaah, baik bagi guru maupun para murid. Disamping itu setiap bulan sekali diadakan pengajian rutin untuk para guru, sehingga suasana kondusif dan harmonis lebih mudah terwujud. Alasan berikutnya adalah adanya kegiatan olah raga bersama yang dikhususkan untuk para guru setiap hari jumat. Olahraga bersama ini dipimpin oleh pelatih dari luar sekolah. Seperti yang telah diketahui, bahwa kegiatan olahraga adalah salah satu cara untuk menangani dan mengendalikan stres, tentunya tidak jarang akan ada kegiatan lainnya seperti berbincang-bincang dan bercanda, sehingga kegiatan ini selain dapat menyegarkan tubuh juga dapat menjadi penyegaran pikiran dan suasana hati para guru tersebut.

Kegiatan rutin lainnya adalah dilaksanakannya rapat setiap minggu sekali yang diikuti oleh para guru dan dipimpin oleh kepala sekolah serta kegiatan Musyawarah Guru Mata Pelajaran (MGMP) yang diadakan setiap satu atau dua minggu sekali. Kegiatan ini merupakan wadah bagi para guru untuk melakukan evaluasi, bertukar ide dan pendapat, juga penyampaian informasi terbaru yang berkaitan dengan kegiatan belajar mengajar. Melalui kegiatan ini para guru saling menerima umpan balik sehingga mengetahui tanggung jawab dan tugas-tugas yang harus dilakukan ke depannya. Selain kegiatan-kegiatan tersebut, para guru juga diikutkan pelatihan, seminar, dan workshop, baik di dalam sekolah maupun di luar sekolah, sehingga pengetahuan, motivasi, keterampilan, dan pengalaman menjadi bertambah. Disamping itu didatangkan native speaker untuk melatih kemampuan guru berbahasa inggris. Selain itu, para guru juga dilatih untuk menguasai teknologi informasi sehingga mempermudah tugas mereka dalam proses belajar mengajar.

\section{KESIMPULAN}

Berdasarkan analisis dan pembahasan pada bagian sebelumnya, maka dapat ditarik kesimpulan sebagai berikut : Hasil uji hipotesis pertama menunjukkan adanya hubungan langsung dan signifikan antara kepuasan kerja guru dengan kinerja guru. Hal ini berarti bahwa kinerja guru semakin baik karena para guru merasa puas akan pekerjaannya. Dengan kinerja guru dalam kegiatan belajar mengajar yang baik mulai dari perencanaan, pengorganisasian, sampai pada penilaian akan meningkatkan mutu akademik lulusan yang ditunjukkan dengan pencapaian nilai ujian nasional yang tinggi.

Hasil uji hipotesis kedua menunjukkan hubungan yang tidak signifikan antara stres kerja guru dangan kinerja guru. Hal ini berarti bahwa meskipun guru cukup mengalami stres terhadap pekerjaannya tetapi tidak mempengaruhi kinerjanya. Sehingga tidak berpengaruh terhadap mutu akademik lulusan siswa.

Berdasarkan hasil penelitian dan kesimpulan dalam penelitian ini, maka ada beberapa rekomendasi yang dapat penulis sampaikan sebagai berikut : (1) Penelitian selanjutnya diharapkan dapat menambah variabel - variabel lain diluar penelitian ini, misalnya : profesionalisme guru, motivasi guru, kepemimpinan kepala sekolah, komitmen organisasi. (2) Penelitian selanjutnya diharapkan dapat membandingkan tingkat kepuasan kerja dan stres kerja antara guru sekolah RSBI dengan guru sekolah reguler dalam mempengaruhi mutu pendidikan di kabupaten Sidoarjo. (3) Upaya-upaya yang harus dilakukan untuk meningkatkan kepuasan terhadap pekerjaan serta meminimalisir stres kerja antara lain 
upaya yang bersifat organisatoris yang terkait dengan bidang pekerjaan yang ditekuni seperti : penempatan kerja sesuai dengan kemampuan individu, menspesifikasi tujuan dan antisipasi hambatan, meningkatkan komunikasi organisasi secara efektif untuk membentuk persepsi yang sama terhadap tujuan pekerjaan, menghindari ketidakpastian peran, penciptaan iklim kerja yang sehat merupakan upaya yang konstruktif untuk meminimalkan terjadinya stres kerja dan meningkatkan kepuasan atas pekerjaan. Upaya-upaya lainnya adalah penyediaan fasilitas fisik, klinik mental, dan bimbingan peningkatan tanggung jawab, yang semuanya ini merupakan langkah positif bersifat organisatoris untuk menghindari terjadinya stres akibat kerja di lingkungan sekolah.

\section{DAFTAR RUJUKAN}

Akhlaq, Muhammad, et al. 2010. An Evaluation of The Effects of Stress on The Job Performance of Secondary School Teachers. Journal of Law and Psycology.

Bhuain N. Shahid, and Menguc, Bulent. 2002. An extention and Evalution of Job Characteristics, Organizational Commitment and Job Satisfaction in an Expatriate, Guest Worker, Sales Setting. Journal Personal Selling and Management. Vol. XXII. No. 1.

Fatah, Nanang. 2001. Landasan Manajemen Pendidikan. Bandung. PT. Remaja Rosdakarya.

Ghozali, Imam. 2006. Partial Least Square. Semarang : Badan Penerbit Universitas Diponegoro.

Ghozali, Imam. 2012. Konsep, Teknik dan Aplikasi SmartPLS 2.0 M3. Semarang : Badan Penerbit Universitas Diponegoro.

Hariwibowo. 1994. Peranan Sistem Evaluasi Pada Setiap dan Antar Jenjang Pendidikan. Jakarta : Grasindo.

Johnson, Sheena, et al. 2005. Observation Piece : The Experience of Work Related Stress Accros Occupations. Journal of Managerial Psycology. Vol 20 No. 20.

Luthans, Fred. 2005. Organizational Behavior. Tenth Edition. Irwin/Mc Grawhill.

Polkamnas. RSBI Tidak Menjamin Peningkatan Mutu Akademis. 20 Maret 2012. Diakses tanggal 30 Maret 2012.

Rivai, Veithzal. 2008. Manajemen Sumber Daya Manusia untuk Perusahaan : Dari Teori ke Praktik. Jakarta : PT Raja Grafindo Persada.

Robbins, S.P. 2003. Organizational behavior. Tenth Edition. Pearson Education International.

Salami, et al. 2010. Impact of Job Stress on Managers Performance. European Journal of Scientific Research. Vol. 45 No. 2, pp 249-260.

Subroto. Cipto, Waspodo. 2010. Insentif dan Implikasinya pada Kinerja Guru dalam Peningkatan Mutu Pendidikan di Sekolah Dasar Kota Surabaya. Jurnal Pendidikan Dasar. Vol. II No. 1. Hal 64-80.

Wexley, Kenneth N. and Yuki, Gary A. 2005. Perilaku Organisasi dan Psikologi Personalia. Edisi Terjemahan. Jakarta : Rineka Cipta.

Yuniastini, dkk. 2005. Analisis Pengaruh Kinerja Dosen dan Proses Belajar Mengajar Terhadap Prestasi Mahasiswa. Jurnal Administrasi Kebijakan Kesehatan. Vol.3 No.2. pp 86-92. 